\title{
Nutritional status and weight gain in pregnant women ${ }^{1}$
}

\author{
Ana Paula Sayuri Sato² \\ Elizabeth Fujimori ${ }^{3}$
}

This study described the nutritional status of 228 pregnant women and the influence of this on birth weight. This is a retrospective study, developed in a health center in the municipality of São Paulo, with data obtained from medical records. Linear regression analysis was carried out. An association was verified between the initial and final nutritional status $(p<0.001)$. The mean of total weight gain in the pregnant women who began the pregnancy underweight was higher compared those who started overweight/obese $(p=0.005)$. Weight gain was insufficient for $43.4 \%$ of the pregnant women with adequate initial weight and for $36.4 \%$ of all the pregnant women studied. However, $37.1 \%$ of those who began the pregnancy overweight/obese finished with excessive weight gain, a condition that ultimately affected almost a quarter of the pregnant women. Anemia and low birth weight were uncommon, however, in the linear regression analysis, birth weight was associated with weight gain $(p<0.05)$. The study highlights the importance of nutritional care before and during pregnancy to promote maternal-infant health.

Descriptors: Nutrition Assessment; Weight Gain; Maternal Nutrition; Prenatal Care; Birth Weight.

\footnotetext{
${ }^{1}$ Supported by CNPq (402295/2005-6).

2 Doctoral Student, Escola de Enfermagem, Universidade de São Paulo, Brazil.

${ }^{3}$ PhD, Associate Professor, Escola de Enfermagem, Universidade de São Paulo, Brazil.
}

Corresponding Author:

Ana Paula Sayuri Sato

Universidade de São Paulo. Escola de Enfermagem

Av. Dr. Enéas de Carvalho Aguiar, 419

Bairro: Cerqueira César

CEP: 05403-000, São Paulo, SP, Brasil

E-mail: sah@usp.br 


\section{Estado nutricional e ganho de peso de gestantes}

Caracterizou-se estado nutricional de 228 gestantes e sua influência no peso ao nascer. Trata-se de estudo retrospectivo desenvolvido num centro de saúde do município de São Paulo, com dados obtidos de prontuários. Realizou-se análise de regressão linear. Verificouse associação entre estado nutricional inicial e final $(p<0,001)$. A média de ganho total de peso diminuiu das gestantes que iniciaram a gravidez com baixo peso para aquelas que iniciaram com sobrepeso/obesidade $(p=0,005)$, sendo insuficiente para 43,4 e $36,4 \%$ das gestantes com peso inicial adequado e para o total das gestantes estudadas, respectivamente. Entretanto, $37,1 \%$ daquelas que iniciaram a gravidez com sobrepeso/ obesidade finalizaram com ganho excessivo, condição que, no final, afetou quase um quarto das gestantes. Anemia e baixo peso ao nascer foram pouco frequentes, porém, na análise de regressão linear, peso ao nascer associou-se com ganho de peso $(p<0,05)$. Evidencia-se a importância do cuidado nutricional antes e durante a gravidez, para promoção da saúde materno-infantil.

Descritores: Avaliação Nutricional; Ganho de Peso; Nutrição Materna; Cuidado Pré-Natal; Peso ao Nascer.

\section{Estado nutricional y aumento de peso en la mujer embarazada}

Estado nutricional de 228 embarazadas y su influencia en el peso al nacer fue caracterizado. Estudio desarrollado en centro de salud de São Paulo con datos obtenidos de registros médicos. Análisis de regresión lineal fue realizado. Se verificó asociación entre estado nutricional inicial y final $(p<0,001)$. La media del aumento total de peso disminuyó de las mujeres que iniciaran el embarazo con bajo peso para las que comenzaron con sobrepeso/ obesidad ( $p=0,005)$, siendo insuficiente para $43,4 \%$ y $36,4 \%$ de embarazadas con peso adecuado inicial y para el total, respectivamente. Sin embargo, $37,1 \%$ de las que comenzaron el embarazo con sobrepeso/obesidad finalizó con ganancia excesiva, condición que afectó casi un cuarto del total. Anemia y bajo peso al nacer fueron poco frecuentes, pero peso al nacer se asoció con aumento materno de peso $(p<0,05)$. El estudio destaca la importancia de la atención nutricional antes y durante el embarazo para promover la salud materna e infantil.

Descriptores: Evaluación Nutricional; Aumento de Peso; Nutrición Materna; Atención Prenatal; Peso al Nacer.

\section{Introduction}

Quality prenatal care involves actions of prevention and health promotion, early diagnosis and the adequate treatment of problems that occur during this period. In this context, for good prenatal monitoring, the evaluation of the initial nutritional status and the monitoring of the gestational weight gain stand out among the recommended technical procedures, as well as the evaluation of the hemoglobin level, which have direct implications on maternal-infant health ${ }^{(1)}$.

Anemia during pregnancy is associated with higher rates of maternal and perinatal morbidity and mortality, with a higher risk for miscarriage, prematurity, low birth weight and infants with iron stores below normal, and therefore at higher risk for developing anemia in the first months of life ${ }^{(2)}$.
Gestational complications, with unfavorable outcomes for mothers and children, have also been associated with both insufficient and excessive gestational weight gain. Among these outcomes low birth weight, macrosomia, preterm birth, cesarean and maternal diabetes and hypertension are prominent ${ }^{(3-4)}$. Furthermore, in addition to the increased risk of perinatal complications, inadequate nutrition during the fetal period is also associated with disease in adulthood(5).

The recommendations regarding the ideal weight gain for the gestational period were much discussed in the 1990 's and considered the limits of weight gain needed to overcome the maternal-fetal demands and to obtain the 
best possible gestational outcome. In Brazil, the Ministry of Health adopts recommendations for total weight gain according to the initial nutritional status of the pregnant woman and classifies the nutritional status according to categories of body mass index (BMI) by gestational week $^{(1)}$. Thus, to evaluate the nutritional status at the beginning of the pregnancy is essential to detect pregnant women at nutritional risk, i.e. with anemia, underweight or overweight/obese; to forecast risk of adverse pregnancy outcome; to determine appropriate recommendations for weight gain; and to perform adequate nutritional guidance for each case. In addition, the monitoring of weight gain is also essential to establish appropriate nutritional interventions.

The present study aimed to describe the nutritional status and weight gain of pregnant women attending a health center of the municipality of São Paulo, and to evaluate the influence of these variables on the birth weight of the child, in order to support the healthcare professionals in the prenatal monitoring.

\section{Method}

This retrospective study was conducted in a health center located in the municipality of São Paulo, as a subproject of a broader study* approved by the Ethics Committee. The data were obtained from the medical records of pregnant women attending the prenatal service between June 2005 and December 2006. A total of 228 pregnant women composed the sample, which included those whose records contained at least the following information: date of the last menstruation; measurement of the height and two measurements of weight, up to the $13^{\text {th }}$ week and after the $37^{\text {th }}$ week of gestation; hemoglobin level $(\mathrm{Hb})$; and birth weight. Socioeconomic and demographic data contained in the records were collected to characterize the pregnant women.

The initial and final nutritional status was evaluated using the BMI, obtained from the measurement of height and weight checked until the $13^{\text {th }}$ week and after the $37^{\text {th }}$ week of gestation, both classified according to gestational age $^{(1)}$. Additionally, the BMI was calculated from all the weight data contained in the records, which made it possible to evaluate the nutritional status during the gestational process. The total weight gain was calculated through the difference between the measurements of weight recorded up to the $13^{\text {th }}$ and after the $37^{\text {th }}$ week and classified according to the criteria of the Ministry of Health(1), that consider the initial nutritional status (Table 1 ).
Table 1 - Recommended weight gain in pregnancy according to the initial nutritional status

\begin{tabular}{lc}
\hline \multicolumn{1}{c}{ Initial nutritional status } & Total gain $(\mathbf{k g})$ \\
\hline Underweight & $12.5-18.0$ \\
Adequate weight & $11.5-16.0$ \\
Overweight & $7.0-11.5$ \\
Obese & 7.0 \\
\hline
\end{tabular}

Source: MH, 2005

Pregnant women with $\mathrm{Hb}$ less than $11 \mathrm{~g} / \mathrm{dL}$ were considered anemic and a birth weight less than $2500 \mathrm{~g}$ was classified as underweight ${ }^{(1)}$. The chi-square test, analysis of variance (ANOVA), Tukey's test, and linear regression (backward stepwise) were used for the data analysis, performed with the software Statistical Package for the Social Sciences and Epi-Info. In the analysis of linear regression the dependent variable was the birth weight of the child and independent variables were the initial and final BMI, the total weight gain during pregnancy and the hemoglobin level. The level of significance of the tests was $5 \%$.

\section{Results}

Table 2, which presents characteristics of the pregnant women, shows that the majority of the women were between 20 and 35 years of age, had a family income of two minimum wages or more, more than eight years of study, lived with a partner, worked and had attended six or more prenatal consultations. The occurrence of anemia and low birth weight was less

Table 2 - Distribution of the pregnant women according to socio-economic and demographic variables, prenatal conditions and low birth weight. São Paulo, SP, Brazil, 2007

\begin{tabular}{lcc}
\hline \multicolumn{1}{c}{ Characteristics } & $\mathbf{n}$ & $\%$ \\
\hline Age (years) & & \\
$\quad>20$ & 43 & 18.9 \\
$20 \mid-35$ & 172 & 75.4 \\
$\quad \geq 35$ & 13 & 5.7 \\
Family income (in minimum wages) ${ }^{*}$ & & \\
$\quad<2$ & 35 & 25.0 \\
$\quad 2$ & 105 & 75.0 \\
Education (years) & & \\
0 - 4 & 21 & 9.2 \\
4 - 8 & 73 & 32.0 \\
$8 \vdash 11$ & 58 & 25.4 \\
$\geq 11$ & 76 & 33.4 \\
\hline
\end{tabular}

*Information was not obtained for all the pregnant women

(continue...)

\footnotetext{
${ }^{*}$ Research project funded by CNPq (Process No. 402295/2005-6).
} 
Table 2 - (continuation)

\begin{tabular}{|c|c|c|}
\hline Characteristics & $\mathbf{n}$ & $\%$ \\
\hline \multicolumn{3}{|l|}{ Conjugal status } \\
\hline With a partner & 168 & 73.7 \\
\hline Without a partner & 60 & 26.3 \\
\hline \multicolumn{3}{|l|}{ Employment } \\
\hline Yes & 124 & 54.4 \\
\hline No & 104 & 45.6 \\
\hline \multicolumn{3}{|l|}{ Initial nutritional status } \\
\hline Underweight & 29 & 12.7 \\
\hline Adequate weight & 129 & 56.6 \\
\hline Overweight/obese & 70 & 30.7 \\
\hline \multicolumn{3}{|c|}{ Number of prenatal consultations } \\
\hline$<6$ & 35 & 15.4 \\
\hline$\geq 6$ & 193 & 84.6 \\
\hline \multicolumn{3}{|l|}{ Previous pregnancies } \\
\hline 0 & 98 & 43.0 \\
\hline $1|-| 2$ & 106 & 46.5 \\
\hline$>2$ & 24 & 10.5 \\
\hline \multicolumn{3}{|l|}{ Anemia } \\
\hline Yes & 10 & 4.4 \\
\hline No & 218 & 95.6 \\
\hline \multicolumn{3}{|l|}{ Birth weight } \\
\hline$<2500$ & 8 & 3.5 \\
\hline$\geq 2500$ & 220 & 96.5 \\
\hline
\end{tabular}

*Information was not obtained for all the pregnant women than $5 \%$, however, nearly a third started the pregnancy overweight/obese.

Figure 1 shows the distribution of the mean BMI of the pregnant women according to gestational age, obtained by calculating the BMI of all weight data contained in the medical records, according to their initial nutritional status (underweight, adequate weight and overweight/ obese). It was found that, in general, the pregnant women maintained the classification of nutritional status, i.e. those who started the pregnancy underweight did not reach the adequate weight range, in the same way, the women who started overweight/obese maintained this nutritional status.

There was a significant association $(p<0.001)$ between the initial and final nutritional status (Table 3 ). Of the women who began the pregnancy underweight, almost $60 \%$ finished underweight. Although two thirds of the pregnant women who began the pregnancy with an adequate nutritional status terminated the pregnancy in the normal range, it was found that around a quarter finished overweight/obese. Of those who began the pregnancy overweight/obese, the majority finished with the same nutritional status, so that in total a high percentage completed the pregnancy overweight/obese (40.8\%).
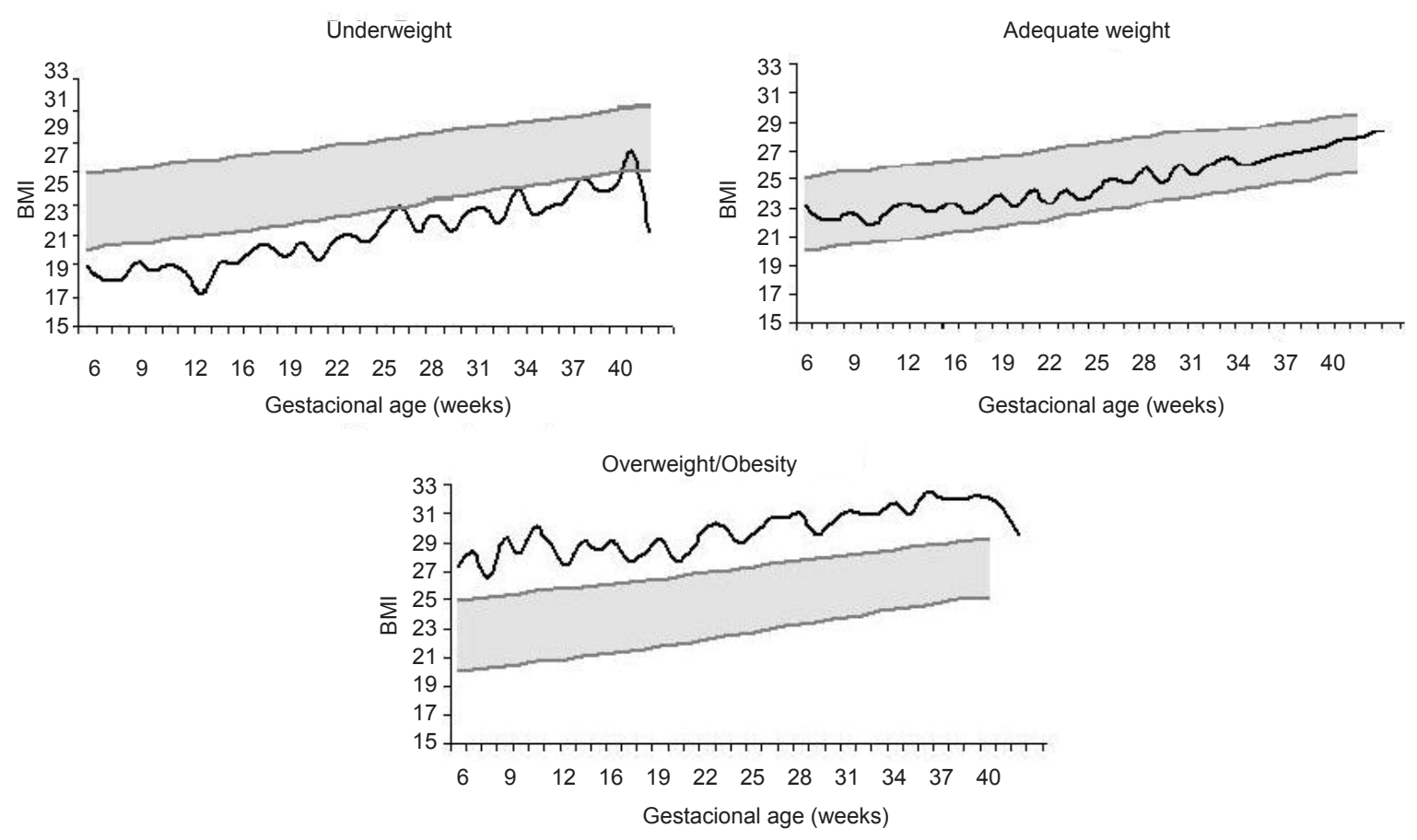

Figure 1 - Distribution of the pregnant women according to mean BMI throughout the pregnancy, according to their initial nutritional status (underweight, adequate weight and overweight/obese), in relation to the normal range. São Paulo, SP, Brazil, 2007 
Table 3 - Final nutritional status of the pregnant women (classified by BMI/gestational age), according to initial nutritional status. São Paulo, SP, Brazil, 2007

\begin{tabular}{lccc}
\hline \multirow{2}{*}{ Initial nutritional status } & \multicolumn{3}{c}{ Final nutritional status $\mathbf{n}(\%)$} \\
\cline { 2 - 3 } & Underweight & Adequate weight & Overweight/obese \\
\hline Underweight & $17(58.6)$ & $11(37.9)$ & $1(3.5)$ \\
Adequate weight & $12(9.3)$ & $86(66.7)$ & $31(24.0)$ \\
Overweight/obese & - & $9(12.9)$ & $61(87.1)$ \\
Total & $29(12.7)$ & $106(46.5)$ & $70(100.0)$ \\
\hline
\end{tabular}

Chi-square: $p<0.001$

Table 4 - Distribution of the pregnant women according to total weight gain and their initial nutritional status. São Paulo, SP, Brazil, 2007

\begin{tabular}{|c|c|c|c|c|c|}
\hline \multirow[b]{2}{*}{ Initial nutritional status } & \multirow[b]{2}{*}{$\mathbf{n}$} & \multicolumn{4}{|c|}{ Total weight gain } \\
\hline & & $\operatorname{Mean}_{ \pm} \mathrm{SD}$ & $\begin{array}{c}\text { Insufficient } \\
\mathrm{n}(\%)\end{array}$ & $\begin{array}{c}\text { Adequate } \\
\text { n(\%) }\end{array}$ & $\begin{array}{c}\text { Excessive } \\
\text { n(\%) }\end{array}$ \\
\hline Underweight & 29 & $13.3 \pm 4.2$ & $10(34.5)$ & $17(58.6)$ & $2(6.9)$ \\
\hline Adequate weight & 129 & $12.1 \pm 4.4$ & $56(43.4)$ & $48(37.2)$ & $25(19.4)$ \\
\hline Overweight/Obese & 70 & $10.3 \pm 5.4$ & $17(24.3)$ & $27(38.6)$ & $26(37.1)$ \\
\hline Total & 228 & $11.73 \pm 4.8$ & $83(36.4)$ & $92(40.3)$ & $53(23.2)$ \\
\hline
\end{tabular}

ANOVA: $p=0.005$; Tukey's test: underweight and overweight/obese $(p=0.011)$; adequate and overweight/obese $(p=0.028)$

The mean of the total weight gain in the pregnant women who started underweight was significantly higher compared those who began the pregnancy overweight/ obese $(p=0.005)$. Nevertheless, it was found that the total gain was insufficient in $43.4 \%$ of the pregnant women with adequate initial weight and $36.4 \%$ for the all the pregnant women studied. Conversely, $37.1 \%$ of the pregnant women who began the pregnancy overweight/ obese finished with excessive weight gain, a condition that ultimately affected almost a quarter of the pregnant women (Table 4).

The linear regression analysis showed that only the total weight gain influenced the birth weight of the child $(p=0.02)$. An increase of $0.279 \mathrm{~g}$ in the birth weight of the child was found for each kilogram of weight gained in the total of the pregnancy. No significant association was observed between birth weight and initial BMI $(p=0.16)$ or final BMI $(p=0.65)$ or maternal hemoglobin level $(p=0.22)$.

\section{Discussion}

This study characterized the nutritional status of pregnant women attending a health center, in order to support the care provided to pregnant women, considering that quality prenatal monitoring favors the prognosis of maternal-infant health(6). The evaluation of the nutritional status showed that a high percentage of the women started the pregnancy overweight/obese, a result slightly higher to that found in other studies developed in the primary healthcare system ${ }^{(7-9)}$. A cohort study that followed more than 3000 women attending general prenatal services of the Brazilian National Health System (SUS) found that $29 \%$ were pre-obese/obese before the pregnancy, a condition that is associated with a greater chance of excessive weight gain ${ }^{(7)}$. Another longitudinal study, conducted with pregnant women attending the Family Health Program of Campina Grande, PB, found $28 \%$ initially overweight/ obese, a condition statistically associated with gestational arterial hypertension and the postpartum nutritional status $^{(8)}$. A descriptive study with 240 pregnant women of low obstetric risk, attending a public prenatal service of the municipality of Recife, PE, verified that $26 \%$ were initially overweight/obese, which was associated with excessive weekly weight gain ${ }^{(9)}$. Furthermore, a high percentage of women finished the pregnancy overweight/obese (40.8\%) because, in addition to those who began pregnancy in this condition, almost one quarter of those who started the pregnancy with adequate weight finished it overweight/ obese. This result is worrying because maternal obesity is associated with increased risk for gestational diabetes, macrosomia, hypertensive disorders, preeclampsia, stillbirth, premature birth and perinatal mortality(10-11).

The importance is evident, therefore, of nutritional care not only during the prenatal period, but in women's healthcare in general, including the periods before and after pregnancy, that is, in all care provided to women of childbearing age. One of the objectives should aim at an adequate nutritional status, so that when becoming pregnant the woman has the weight expected for their height, and after delivery receives monitoring to prevent 
postpartum weight retention(12), especially considering recent data, which show that excess weight affects about half of Brazilian women ${ }^{(13)}$.

The analysis of total weight gain showed, however, that the pregnant women initially overweight/obese gained significantly less weight than those who began the pregnancy underweight and those with adequate nutritional status (Table 3 ). This result could indicate that there was some intervention aiming to control weight gain, however, it seems to have been ineffective, because $37.1 \%$ of the pregnant women who began the pregnancy overweight/ obese and $23.2 \%$ of all the pregnant women presented excessive weight gain. This is a condition known to be an important predictor of postpartum weight retention ${ }^{(14)}$, which in turn is one of the key elements for the future development of obesity in women ${ }^{(15)}$, which can be minimized by nonexcessive weight gain during pregnancy ${ }^{(12,14)}$.

In the United States of America, a study with 120,531 pregnant women in five states showed that $42 \%$ presented weight gain higher than recommended(16). In Brazil, a study conducted in six state capitals verified that $29 \%$ of the pregnant women presented excessive weight gain, rising to $50 \%$ among those initially overweight and $38 \%$ among those with obesity ${ }^{(7)}$. Other studies also found high percentages of pregnant women with weight gain above the recommended: $29 \%$ in Rio de Janeiro(17); $36 \%$ in Sao Paulo(18); 39\%, 44\% and 56\% in pregnant women who started the pregnancy underweight, with adequate weight and overweight/obese, respectively, in $\operatorname{Recife}^{(9)} ; 44 \%$ in Campina Grande, $\mathrm{PB}^{(8)}$; and $45 \%$ in Rio Grande do Sul ${ }^{(11)}$. In addition to being associated with pre-gestational overweight/ obesity, excessive weight gain has been associated with the social variables of the women, such as better education and stable marital status (with partner) ${ }^{(9)}$. It is noteworthy that in the present study, a higher proportion of women started the pregnancy overweight/obese, had more than 8 years of study and lived with a partner.

A systematic literature review showed that the effect of interventions based on dietary guidance and change of lifestyle in the prenatal period of overweight/ obese women remains unclear(19). Thus, it reinforces the importance of promoting the adequate nutritional status of women in the pre-gestational period, both in order to prevent adverse maternal-fetal outcomes, and to prevent postpartum weight retention.

Although many studies emphasize excessive weight gain as an issue that requires immediate attention in the prenatal services ${ }^{(3-4,8-9,11,17-18)}$, the finding that a high percentage of pregnant women presented insufficient weight gain (36.4\%) is also disturbing, a situation that is associated with increased risk of premature birth and low birth weight ${ }^{(4,20)}$. These findings reinforce the importance of nutritional monitoring in the prenatal period, which should focus on modifiable variables, such as weight gain and the diet, and benefits women at risk of both excessive and insufficient weight gain ${ }^{(21)}$, through the monitoring of weight gain and guidance on healthy eating practices ${ }^{(1)}$.

Another important nutritional problem during pregnancy, gestational anemia, presented low prevalence among the pregnant women studied, as already found in a previous study ${ }^{(22)}$, however, it certainly stems from the fact that the pregnant women included in this study had a maximum of 13 weeks of gestation, a period in which the extra-basal iron necessity is not yet evident.

The linear regression analysis showed that the only maternal variable associated with the birth weight was the total weight gain during pregnancy, a result that can be justified by the low frequency of children with low birth weight, since other studies have found a positive correlation between birth weight and maternal pre-gestational height, weight and BMI, as well as total weight gain ${ }^{(4,20)}$.

Despite the relevance of the theme, a study that evaluated nutritional guidance in the prenatal care of primary health units revealed that the majority of the pregnant women received no such guidance, even with early participation in the prenatal care and an adequate number of consultations, a result that highlights deficiencies in the nutritional care and in the quality of the prenatal care ${ }^{(23)}$. We agree with the authors of this study that the qualification of prenatal care involves "the practice of professionals prepared to identify pregnant women at nutritional risk, through the early evaluation of nutritional status, and to perform individualized nutritional guidance aiming for optimization of the maternal nutritional status, improvement of the maternal conditions for the delivery and an appropriate weight for the newborn"(23). Thus, this refers to the need to revise nutritional education in the healthcare area courses, considering that it was evidenced in the 1990's that physicians and nurses had deficient training and difficulty to identify and address problems related to nutrition ${ }^{(24)}$.

\section{Final considerations}

Although having been performed in a single health service, the study shows the importance of nutritional care before and during pregnancy to promote maternal-infant health. The approach regarding the diet and nutritional status must integrate attention to the health of women of reproductive age, searching for the maintenance of an adequate pre-gestational weight, especially regarding the prevention of becoming overweight. During the prenatal period, special attention should be given to the total weight gain, which is associated with the birth weight of the child, and if excessive, with future obesity. 


\section{References}

1. Ministério da Saúde (BR). Secretaria de Atenção

à Saúde. Departamento de Ações Programáticas Estratégicas. Área Técnica de Saúde da Mulher. Pré-natal e puerpério: atenção qualificada e humanizada - manual técnico. Brasília: Ministério da Saúde; 2005.

2. Zimmermann MB, Hurrell RF. Nutritional iron deficiency. Lancet. 2007;370(9586): 511-20.

3. Crane JM, White J, Murphy $P$, Burrage L, Hutchens D. The effect of gestational weight gain by body mass index on maternal and neonatal outcomes. J Obstet Gynaecol Can. 2009;31(1):28-35.

4. Frederick IO, Williams MA, Sales AE, Martin DP, Killien M. Pre-pregnancy body mass index, gestational weight gain, and other maternal characteristics in relation to infant birth weight. Matern Child Health J. 2008;12(5):557-67.

5. Zadik Z. Maternal nutrition, fetal weight, body composition and disease in later life. J Endocrinol Invest. 2003;26:941-6.

6. Calderon IMP, Cecatti JG, Veja CEP. Intervenções benéficas no pré-natal para prevenção da mortalidade materna. Rev Bras Ginecol Obstet. 2006;28:310-5.

7. Nucci LB, Duncan BB, Mengue SS, Branchtein L, Schmidt MI, Fleck ET. Assessment of weight gain during pregnancy in general prenatal care services in Brazil. Cad Saúde Pública. 2001;17(6):1367-74.

8. Assunção PL, Melo ASO, Gondim SSR, Benício MHDR, Amorim MMR, Cardoso MAA. Ganho ponderal e desfechos gestacionais em mulheres atendidas pelo Programa de Saúde da Família em Campina Grande, PB (Brasil). Rev Bras Epidemiol. 2007; 10(3):352-60.

9. Andreto LM, Souza AI, Figueiroa JN, Cabral-Filho JE. Fatores associados ao ganho ponderal excessivo em gestantes atendidas em um serviço público de pré-natal na cidade de Recife, Pernambuco, Brasil. Cad Saúde Pública. 2006;22(11):2401-9.

10. Galtier-Dereure F, Boegner C, Bringer J. Obesity and pregnancy: complications and cost. Am J Clin Nutr. 2000;71 Suppl:1242-8.

11. Drehmer M, Camey S, Schmidt MI, Olinto MTA, Giacomello A, Buss C, et al. Socioeconomic, demographic and nutritional factors associated with maternal weight gain in general practices in Southern Brazil. Cad Saúde Pública. 2010;26(5):1024-34.

12. Castro MBT, Kac G, Sichieri R. Determinantes nutricionais e sócio demográficos da variação de peso no pós-parto: uma revisão da literatura. Rev Bras Saúde Mater Infant. 2009;9(2):125-37.

13. Instituto Brasileiro de Geografia e Estatística (IBGE). Pesquisa de Orçamentos Familiares, 2008-2009. Rio de Janeiro; IBGE; 2010. [acesso 5 abr 2011]. Disponível em: http://www.ibge.gov.br/home/estatistica/populacao/ condicaodevida/pof/2008_2009_encaa/pof_20082009_ encaa.pdf

14. Scholl TO, Hediger ML, Schall JI, Ances IG, Smith WK. Gestacional weight gain, pregnancy outcome and postpartum weight retention. Obstet Gynecol. 1995;86(3): 423-7.

15. Rooney BL, Schauberger CW. Excess pregnancy weight gain and long-term obesity: one decade later. Obstest Gynecol. 2002;100(2):245-52.

16. Schieve LA, Cogswell ME, Scanlon KS. Trends in pregnancy weight gain within and outside ranges recommended by the Institute of Medicine in a WIC population. Matern Child Health J. 1998;2(2):111-6.

17. Kac G, Velásques-Meléndez G. Ganho de peso gestacional e macrossomia em uma coorte de mães e filhos. J Pediatria. 2005;81(1):47-53.

18. Stulbach TE, Benício MHA, Andreazza R, Konno SC. Determinantes do ganho ponderal excessivo durante a gestação em serviços públicos de pré-natal de baixo risco. Rev Bras Epidemiol. 2007;10(1):99-108.

19. Dodd JM, Grivell RM, Crowther CA, Robinson JS. Antenatal interventions for overweight or obese pregnant women: a systematic review of randomized trials. BJOG. 2010;117:1316-26.

20. Rocha DS, Netto MP, Priore SE, Liiva NMM, Rosado LEFPL, Franceschini SCC. Estado nutricional e anemia ferropriva em gestantes: relação com o peso da criança ao nascer. Rev Nutr Campinas 2005;18(4):481-9.

21. Brawarsky $P$, Stotland $N E$, Jackson RA, FuentesAfflick E, Escobar GJ, Rubashkin N, et al. Pre-pregnancy and pregnancy-related factors and the risk of excessive or inadequate gestational weight gain. Int J Gynaecol Obstet. 2005;91:125-31.

22. Sato APS, Fujimori E, Szarfarc SC, Sato IC. Prevalência de anemia em gestantes e a fortificação de farinhas com ferro. Texto Contexto. Enferm. 2008;17(3):481-9.

23. Santos LA, Mamede FV, Clapis MJ, Bernardi JVB. Orientação nutricional no pré-natal em serviços públicos de saúde no município de Ribeirão Preto: o discurso e a prática assistencial. Rev. Latino-Am. Enfermagem. 2006;14(5):688-94.

24. Boog MCF. Educação nutricional em serviços públicos de saúde. Cad Saúde Pública. 1999;15 Suppl 2:139-47. 